\title{
Brachymeria pandora (Crawford) (Hymenoptera, Chalcididae): a new parasitoid of Historis odius (Fabricius) (Lepidoptera, Nymphalidae)
}

\author{
Hélcio R. Gil-Santana ${ }^{1} \&$ Marcelo T. Tavares ${ }^{2}$ \\ 1 Laboratório de Diptera, Departamento de Entomologia, Instituto Oswaldo Cruz. Avenida Brasil 4365, Manguinhos, 21045 - \\ 900 Rio de Janeiro, Brasil.E-mail: helciogil@uol.com.br \\ ${ }_{2}^{2}$ Departamento de Ciências Biológicas, Universidade Federal do Espírito Santo. Avenida Marechal Campos 1468, 29040 - \\ 090 Vitória, Espírito Santo, Brasil. E-mail: mtavares@npd.ufes.br
}

\begin{abstract}
The first record of parasitism of Brachymeria pandora (Crawford, 1914) (Hymenoptera, Chalcididae) on Historis odius (Fabricius, 1775) (Lepidoptera, Nymphalidae) in the State of Rio de Janeiro, Brazil is presented. KEY WORDS. Cabo Frio, parasitoid.

RESUMO. Brachymeria pandora (Crawford) (Hymenoptera, Chalcididae): um novo parasitóide de Historis odius (Fabricius) (Lepidoptera, Nymphalidae). Apresenta-se o primeiro registro de parasitismo de Brachymeria pandora (Crawford, 1914) (Hymenoptera, Chalcididae) em Historis odius (Fabricius, 1775) (Lepidoptera, Nymphalidae), no estado do Rio de Janeiro, Brasil.
\end{abstract}

PALAVRAS CHAVE. Cabo Frio, parasitóide.

Historis odius (Fabricius, 1775) is a well-known butterfly species that ranges widely over Latin America, including the Caribbean Islands and even isolated Coco Island, where it is the only resident butterfly (Hogue 1993). The species can be found throughout the Region from Southern United States to Argentina and West Indies (D'Abrera 1984).

The larvae of $H$. odius feed on the leaves of Cecropia spp. (Urticales, Moraceae) (Hogue 1993). The chrysalid has fine, forktipped, dorsal abdominal spines and curved head horns (Hogue 1993) (Fig. 1).

Brachymeria pandora (Crawford, 1914) (Fig. 2) was already found in Guiana (CRAWFORD 1914) as a parasitoid of larva of an undetermined species Hesperiidae and Venezuela (Teran 1980) as parasitoid of pupa Calpodes ethlius (Stoll, 1780) (Lepidoptera, Hesperiidae).

Some pupae of Historis odius were collected by the first author at Cabo Frio $\left(22^{\circ} 51^{\prime} \mathrm{S}, 42^{\circ} 03^{\prime} \mathrm{W}\right)$, State of Rio de Janeiro. From two of them, found in 29.V.2000 and XI.2004, emerged 12 and 7 specimens of B. pandora (Fig. 2), respectively. Close species of B. pandora, e. g., B. mnestor (Walker, 1841) and $B$. annulata (Fabricius, 1793) are also gregarious parasitoids of pupae of some families of Lepidoptera, as Noctuidae, Nymphalidae, Papilionidae, Pieridae and Pyralidae (Noyes 2002).

The lepidopteran species was identified based on D'ABRERA (1984, 1987), Brown (1992) and Hogue (1993) and are depos- ited at "Coleção Entomológica do Museu Nacional da Universidade Federal do Rio de Janeiro" (MNRJ). The chalcidid voucher specimens are deposited at "Coleção Entomológica do Departamento de Ciências Biológicas da Universidade Federal do Espírito Santo" (UFES).

\section{ACKNOWLEDGEMENTS}

The first author thanks to the Entomologists Eurides Furtado and Nirton Tangerini for informations about Historis odius.

\section{REFERENCES}

Brown JR., K.S. 1992. Borboletas da Serra do Japi: diversidade, hábitos, recursos alimentares e variação temporal, p. 142187. In: L.P.C. Morellato (Ed.). História Natural da Serra do Japi, ecologia e preservação de uma área florestal no Sudeste do Brasil. Campinas, Universidade Estadual de Campinas, FAPESP, 321p.

Crawford, J.C. 1914. New parasitic Hymenoptera from British Guiana. Proceedings of the Entomological Society of Washington, Washington, 16 (2): 85-88.

D'Abrera, B. 1984. Butterflies of South America. Victoria, Hill House, 256p.

D'Abrera, B. 1987. Butterflies of the Neotropical Region. Part III Brassolidae, Acraeidae, Nymphalidae (partim). 


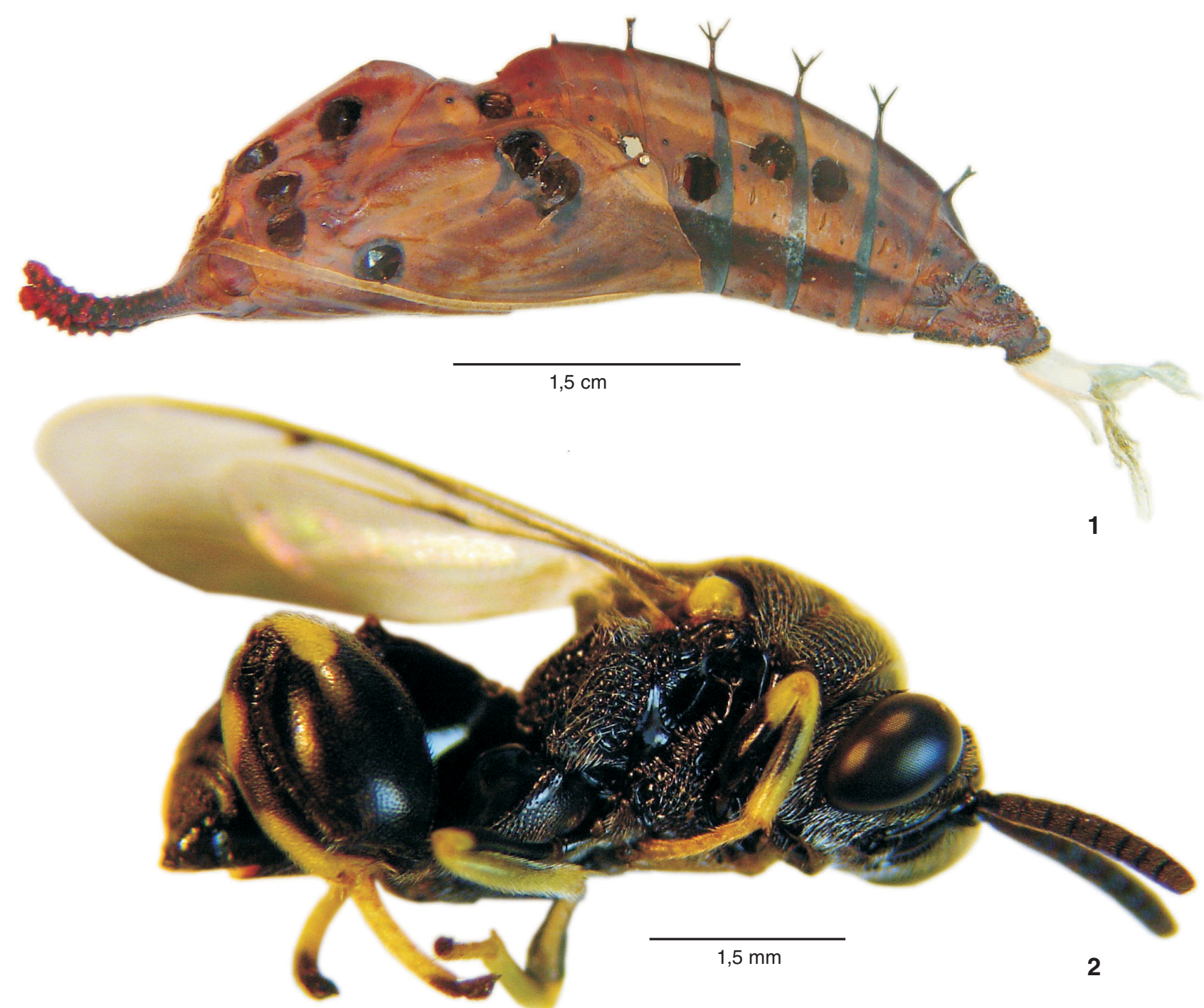

Figures 1-2. (1) Pupa of Historis odius after emergence of the Brachymeria pandora adults, lateral view; (2) adult of Brachymeria pandora, lateral view.

Victoria, Hill House, 140p.

Hogue, C.L. 1993. Latin American insects and entomology. Los Angeles, University of California Press, 536p.

NOYES, J.S. 2002. Interactive catalogue of world Chalcidoidea,
2001. Vancouver, Taxapad, CD-ROM.

Teran, B.J. 1980. Lista preliminar de Hymenoptera parasitos de otros insectos em Venezuela. Revista Facultad de Agronomia, Maracay, 11 (1-4): 283-389.

Received in 26.IV.2005; accepted in 29.IX.2005. 